\title{
Studies on Physico-chemical Characters and Storage Behavior of Blended Cashew Apple Juice Powder for RTS Beverage
}

\author{
K. Umamaheswara Rao*, B. Prasanna Kumar, D. V. Swami, \\ B. Salomi Sunnetha, K. Uma Krishna and D. D. Smith \\ AICRP on Cashew, Cashew Research Station, Dr. Y.S.R. Horticultural University, \\ Bapatla, Andhra Pradesh, India \\ *Corresponding author
}

\author{
A B S T R A C T
}

\section{Keywords}

Cashew Apple Juice

Powder,

Anacardium

occidentale

\section{Article Info}

Accepted:

07 November 2020

Available Online:

10 December 2020
Cashew (Anacardium occidentale L.) belongs to family Anacardiaceae is one of the important dry land plantation crop cultivated in India, ranks third in its export value in the international trade for its kernels. Cashew apple juice is highly perishable when fresh, often spoils within a day. The juice contains tannins, which causes astringency and needs removal to improve the quality of juice. The RTS beverage was prepared by using $1 \mathrm{~g}$ of spray dried blended cashew apple juice powder along with $5 \mathrm{~g}$ of sugar and $94 \mathrm{ml}$ of water and made to $100 \mathrm{ml}$ quantity of RTS. Among the blended cashew apple juice powder treatment combinations, the highest $\mathrm{pH}$ of 3.44 was recorded in $\mathrm{B}_{3}$ (75\% cashew apple juice $+25 \%$ pine apple juice powder at $150{ }^{\circ} \mathrm{C}$ inlet temperature with flow rate of 10 $\mathrm{ml} / \mathrm{min})$ and the lowest was recorded in $\mathrm{B}_{4}\left(100 \%\right.$ cashew apple juice at $150{ }^{\circ} \mathrm{C}$ inlet temperature with flow rate of $10 \mathrm{ml} / \mathrm{min}$ ) (3.38). Among the blended juice treatment combinations, the highest total soluble solids of $10.61{ }^{\circ}$ Brix was recorded in $\mathrm{B}_{4}(100 \%$ cashew apple juice at $150{ }^{\circ} \mathrm{C}$ inlet temperature with flow rate of $10 \mathrm{ml} / \mathrm{min}$ ).

\section{Introduction}

Cashew (Anacardium occidentale L.) belongs to family Anacardiaceae is one of the important dry land plantation crop cultivated in India, ranks third in its export value in the international trade for its kernels. It is native of Brazil and well distributed in both tropical and sub-tropical region of the world. In India, it covers an area of 10.62 lakh hectares with an annual nut production of 8.17 lakh tonnes with an average productivity of $753 \mathrm{~kg} \mathrm{ha}^{-1}$. It is grown in 17 states which include Kerala,
Tamil Nadu, Maharashtra, Goa, Karnataka, Andhra Pradesh, Orissa, West Bengal, Chattisgarh, Jharkhand, Tripura, Meghalaya and Assam. In Andhra Pradesh it cultivated in an area of 1.85 lakh hectares with an annual nut production of one lakh tonnes with an average productivity of $646 \mathrm{~kg} \mathrm{ha}^{-1}$ (Hubbali, 2019). In Andhra Pradesh, cashew is mostly grown in Srikakulam, Vizianagaram, Vishakhapatnam, East Godavari, West Godavari, Krishna, Guntur, Prakasam and Nellore districts. 
The cashew is having commercial value for its cashew nut and its peduncle (false fruit) called cashew apple to which the kidney shaped nut is attached. The production of cashew apple in India is about 65.36 lakh tones (Hubbali, 2019). Cashew apple, the pseudo-fruit is fibrous, juicy and weighs approximately 6-8 times of the nut. Cashew apples are quite nutritious, rich in polyphonelos, minerals, organic acids, carbohydrates, pigments and vitamins mainly vitamin C (Chempakam, 1983). It is having nutritional importance for its therapeutic properties and value-added applications, but around $90 \%$ of the harvest gets wasted (Azevedo and Rodriguez, 2000) and the remaining $10 \%$ of harvested apple is either consumed as fresh or processed industrially into a variety of products such as juices, syrups, canned fruits, pickles, jams, chutneys, candies, toffees, ice creams, vinegar, marmalade and distilled products (Maciel et al., 1986; Nanjundaswamy, 1984). Juice blending is one of the best methods to improve the nutritional quality of juice. It can improve the vitamins and mineral contents depending upon the kind and quality of fruits and vegetables used (Carvalho et al., 2007).

Requirements of the consumers concerning convenience, food safety, health benefits and sensory quality has increased demand for fruit juices but most consumers do not have time to spend in preparing them, requiring ready-touse or easy-to-prepare products. Instant juice powders can meet consumer requirements being cheap to transport and with prolonged shelf life as reported by Cano-Chauca et al., (2005). Moreover Shrestha et al., (2007) enumerated benefits and economic potentials of fruit juice powders over their liquid counterparts as reduced volume or weight, reduced packaging, easier handling and transportation and much longer shelf life. Besides their physical state provides a stable, natural and easily dosable ingredient, which generally finds usage in many foods and pharmaceutical products such as flavoring and coloring agents.

\section{Materials and Methods}

\section{Clarification of juice}

Cashew apple juice is highly perishable when fresh, often spoils within a day. The juice contains tannins, which causes astringency and needs removal to improve the quality of juice. The cashew apple juice was strained through a muslin cloth and collected into a wide mouth stainless steel container, then the clarifying agent, cooked sago@2 g + citric acid@2.5 g / liter of juice was added slowly by stirring the juice in a circular motion till the entire juice formed into curd like precipitate. The precipitate was allowed to stand for 8 hours and the clear supernatant was collected slowly without disturbing the residue. The clear juice obtained was strained through a muslin cloth was used in the experiment.

\section{Preparation of different blended juices}

The fruit juices prepared after extraction from mango, orange, pineapple and cashew apple were blended in the ratio of 75:25 viz., cashew apple juice with other fruit juices and the observations were recorded for different parameters of blended juices.

\section{Procedure}

The blended juice was prepared for the treatments from $\mathrm{T}_{1}-\mathrm{T}_{9}$ by addition of cashew apple juice with mango juice in proportion of $75 \mathrm{ml}+25 \mathrm{ml}$. The blended juice was prepared for the treatments from $\mathrm{T}_{10}-\mathrm{T}_{18}$ by addition of cashew apple juice with orange juice in proportion of $75 \mathrm{ml}+25 \mathrm{ml}$. The blended juice was prepared for the treatments from $\mathrm{T}_{19}-\mathrm{T}_{27}$ by addition of cashew apple 
juice with pineapple juice in proportion of 75 $\mathrm{ml}+25 \mathrm{ml}$. The treatments from $\mathrm{T}_{28}-\mathrm{T}_{36}, 100$ $\%$ cashew apple juice was taken. The details of the treatments are mentioned in page numbers 68-70.

\section{Carriers}

The carrier material used for microencapsulation was maltodextrin obtained from Himedia laboratories limited, India. Matodextrin is a non sweet, soluble to white to off white, slightly hygroscopic powder having 20 Dextrose Equivalence. Maltodextrin (MD) which is the most common carrier used because of its neutral colour, taste and relatively low cost. Maltodextrin is considered as hydrolyzed starch and it is obtained by the action of either acids or enzymes. The addition of MD in food material prior to spray drying can reduce stickiness and agglomeration problems during storage of the end product.

\section{Addition of maltodextrin}

Then the blended juice was mixed with maltodextrin@15\% i.e $15 \mathrm{~g}$ for $100 \mathrm{ml}$ of blended juice by proper homogenization as followed by Rafeekher et al., (2015). Juice carrier concentration in the ratio of 40:60 based on total soluble solids of juice was subjected to spray drying by mixing $100 \mathrm{ml}$ of juice and carrier material.

\section{Homogenization}

After addition of maltodextrin to the blended cashew apple juice, it was homogenized thoroughly by using glass rod as a stirrer and was used for preparation of powder.

\section{Production of blended juice powder}

At specified inlet air temperature water was fed into the nozzle atomizer by peristaltic pump. The feed rate of the water adjusted as to maintain outlet temperature of the air at 88 $\pm 2{ }^{\circ} \mathrm{C}$ throughout the drying process. When the inlet air temperature is desired temperature and the outlet air temperature was stabilized at $88 \pm 2{ }^{\circ} \mathrm{C}$, prepared feed mix was fed into the feed bowl. The feed mix after automization was mixed thoroughly with the hot air in the drying chamber and instantly converted into powder.

The powder particle were collected in the conical bottom of the drying chamber and then carried by the air into the cyclone separator. In the cyclone separator powder particles were from the air and get collected in a jar. Air was let out to the atmosphere. Loose powder remaining in the drying chamber also was collected by capping with clean cloth. Powder form cyclone and loose powder from chamber was separately weighed and then bulked.

\section{Collection of spray dried blended juice powder}

Spray dried juice powder was collected in borosil glass bottles and evaluated for their physical and chemical parameters.

\section{Selection of best powders}

Statistical analysis was done based on three factor completely randomized design and selected three best treatments with higher powder recovery from blended juice powder combinations and one best treatment from $100 \%$ cashew apple juice powder.

\section{Reconstitution of the blended juice powder and preparation of the rts beverage}

The four best treatments were selected from the experiment-1 and required quantity of powder was prepared for reconstitution of the powder for preparation of RTS beverage. 


\section{Preparation of ready to serve (RTS)}

Ready-to-serve beverage (RTS) is a type of fruit beverage which contains at least 10 per cent fruit juice and 10 per cent total soluble solids besides about $0.3 \%$ citric acid. It is not diluted before serving, hence it is known as ready-to-serve beverage (Srivastava and Kumar, 2002).

\section{Procedure}

The RTS beverage was prepared by using $1 \mathrm{~g}$ of spray dried blended cashew apple juice powder along with $5 \mathrm{~g}$ of sugar and $94 \mathrm{ml}$ of water and made to $100 \mathrm{ml}$ quantity of RTS. The blend combination of $\mathrm{B}_{1}$ contains $1 \mathrm{~g}$ of spray dried blended cashew apple juice powder i.e $75 \%$ cashew apple juice $+25 \%$ pineapple juice spray dried at $170{ }^{\circ} \mathrm{C}$ with flow rate of $10 \mathrm{ml} / \mathrm{min}$ along with $5 \mathrm{~g}$ of sugar and $94 \mathrm{ml}$ of water and made up to $100 \mathrm{ml}$ RTS. The blend combination of $B_{2}$ contains 1 $\mathrm{g}$ of spray dried blended cashew apple juice powder i.e $75 \%$ cashew apple juice $+25 \%$ pineapple juice spray dried at $160{ }^{\circ} \mathrm{C}$ with flow rate of $10 \mathrm{ml} / \mathrm{min}$ along with $5 \mathrm{~g}$ of sugar and $94 \mathrm{ml}$ of water and made up to $100 \mathrm{ml}$ RTS. The blend combination $\mathrm{B}_{3}$ contains $1 \mathrm{~g}$ of spray dried blended cashew apple juice powder i.e $75 \%$ cashew apple juice $+25 \%$ pineapple juice spray dried at $150{ }^{\circ} \mathrm{C}$ with flow rate of $10 \mathrm{ml} / \mathrm{min}$ along with $5 \mathrm{~g}$ of sugar and $94 \mathrm{ml}$ of water and made up to $100 \mathrm{ml}$ RTS.

The blend combination $\mathrm{B}_{4}$ contains $1 \mathrm{~g}$ of spray dried $100 \%$ cashew apple juice spray dried at $150{ }^{\circ} \mathrm{C}$ with flow rate of $10 \mathrm{ml} / \mathrm{min}$ along with $5 \mathrm{~g}$ of sugar and $94 \mathrm{ml}$ of water and made up to $100 \mathrm{ml}$ RTS. These were hot filled in sterilized bottle of $200 \mathrm{ml}$ size and crown corked and heat processed in boiling water at $65{ }^{\circ} \mathrm{C}$ for $30 \mathrm{~min}$ then cooled and stored as stated by Srivastava and Kumar (2002).
In this experiment the four best spray dried blended juice powders selected from the first experiment were reconstituted by adding spray dried juice powder and RTS beverage was prepared. The RTS beverages of different treatments were stored in ambient and refrigerated conditions. The quality parameters of the beverage were studied at different days of storage i.e. $0,15,30,45$ and 60 days after storage. The experiment was designed in 3 factorial CRD with two replications containing 40 treatments.

\section{Results and Discussion}

The experiment preambles the utilization of cashew apple juice blended with other fruit juice powder prepared with pineapple combination which found to be best and best treatment of $100 \%$ cashew apple juice powder by spray drying technique are used in the preparation of RTS beverage.

\section{pH}

Among the blended cashew apple juice powder treatment combinations, the highest $\mathrm{pH}$ of 3.44 was recorded in $\mathrm{B}_{3}$ (75\% cashew apple juice $+25 \%$ pine apple juice powder at $150{ }^{\circ} \mathrm{C}$ inlet temperature with flow rate of 10 $\mathrm{ml} / \mathrm{min}$ ) and the lowest was recorded in $\mathrm{B}_{4}$ (100\% cashew apple juice at $150{ }^{\circ} \mathrm{C}$ inlet temperature with flow rate of $10 \mathrm{ml} / \mathrm{min}$ ) (3.38). Among the different storage conditions, the highest $\mathrm{pH}$ was recorded in $\mathrm{C}_{2}$ (refrigerated condition) of 3.46 and lowest was recorded in $\mathrm{C}_{1}$ (ambient condition) of 3.38. Among the different days of storage the highest $\mathrm{pH}$ was recorded in $\mathrm{S}_{1}$ (0 day of storage) of 3.57 and lowest was recorded in $\mathrm{S}_{5}$ $\left(60^{\text {th }}\right.$ day of storage) of 3.20 (Table-1).

The $\mathrm{pH}$ of different blended juice treatment combinations varied from 3.55 to 3.59 at initial day of storage. Among the interaction effects of blended juice treatment 
combinations, storage conditions and days of storage recorded the highest $\mathrm{pH}$ in treatment combination of $\mathrm{C}_{2} \mathrm{~B}_{3} \mathrm{~S}_{2}$ (75\% cashew apple juice $+25 \%$ pineapple juice at inlet temperature of $150{ }^{\circ} \mathrm{C}$ with flow rate of 10 $\mathrm{ml} / \mathrm{min}$ under refrigerated condition at $15^{\text {th }}$ day of storage) of 3.54 followed by $\mathrm{C}_{2} \mathrm{~B}_{2} \mathrm{~S}_{2}$ (75\% cashew apple juice $+25 \%$ pineapple juice at inlet temperature of $160{ }^{\circ} \mathrm{C}$ with flow rate of $10 \mathrm{ml} / \mathrm{min}$ under refrigerated condition at $15^{\text {th }}$ day of storage) of 3.53 and the lowest was recorded in $\mathrm{C}_{1} \mathrm{~B}_{4} \mathrm{~S}_{5}(100 \%$ cashew apple juice at inlet temperature of $150{ }^{\circ} \mathrm{C}$ with flow rate of $10 \mathrm{ml} / \mathrm{min}$ under ambient condition at $60^{\text {th }}$ day of storage) of 2.99 (Table -3 ).

The $\mathrm{pH}$ decreased with gradual passage of storage time. Awsi and Masih (2012) reported that blended juice beverage of pineapple, carrot and orange was stored in pet bottles at refrigerated temperature for 21 days and observed a decrease in the $\mathrm{pH}$ of the juice gradually during the storage period. The reduction in $\mathrm{pH}$ during storage of cashew apple RTS is due to increased levels of sugars by hydrolysis and decreased levels of acidity as reported by Rustagi and Kumar (2013) in amla-mango blends.

\section{Total Soluble Solids ( ${ }^{\circ}$ brix $)$}

Among the blended juice treatment combinations, the highest total soluble solids of $10.61{ }^{\circ}$ Brix was recorded in $\mathrm{B}_{4}(100 \%$ cashew apple juice at $150{ }^{\circ} \mathrm{C}$ inlet temperature with flow rate of $10 \mathrm{ml} / \mathrm{min}$ ) followed by $B_{3}$ (75\% cashew apple juice $+25 \%$ pine apple juice powder at $150{ }^{\circ} \mathrm{C}$ inlet temperature with flow rate of $10 \mathrm{ml} / \mathrm{min}$ ) of $10.56{ }^{\circ} \mathrm{Brix}$ and the lowest was recorded in $\mathrm{B}_{1}(75 \%$ cashew apple juice $+25 \%$ pine apple juice powder at 170 ${ }^{\circ} \mathrm{C}$ inlet temperature with flow rate of 10 $\mathrm{ml} / \mathrm{min}$ ) of $10.41^{\circ}$ Brix.

Among the different storage conditions, the highest total soluble solids ( ${ }^{\mathrm{D}}$ Brix) was recorded in $\mathrm{C}_{1}$ (ambient condition) of 10.55 ${ }^{\circ}$ Brix and lowest was recorded in $\mathrm{C}_{2}$ (refrigerated condition) of $10.46{ }^{\circ}$ Brix. Among the different days of storage the highest total soluble solids ( ${ }^{\circ}$ Brix) was recorded in $S_{5}\left(60^{\text {th }}\right.$ day of storage) of 10.99 ${ }^{0}$ Brix and lowest was recorded in $\mathrm{S}_{1}$ (0 day of storage) of $10.09^{\circ}$ Brix (Table- 1 ).

The total soluble solids of different blended juice treatment combinations varied from 10.00 to 10.28 ( ${ }^{\circ}$ Brix) at initial day of storage. Among the interaction effects of blended juice treatment combinations, storage conditions and days of storage recorded the highest total soluble solids in treatment combination of $\mathrm{C}_{1} \mathrm{~B}_{4} \mathrm{~S}_{5}$ (100\% cashew apple juice at inlet temperature of $150{ }^{\circ} \mathrm{C}$ with flow rate of $10 \mathrm{ml} / \mathrm{min}$ under ambient condition at $60^{\text {th }}$ day of storage) of $11.28{ }^{\circ}$ Brix followed by $\mathrm{C}_{1} \mathrm{~B}_{3} \mathrm{~S}_{5}$ (75\% cashew apple juice $+25 \%$ pineapple juice at inlet temperature of $150{ }^{\circ} \mathrm{C}$ with flow rate of $10 \mathrm{ml} / \mathrm{min}$ under ambient condition at $60^{\text {th }}$ day of storage) of 11.18 ${ }^{\circ}$ Brix and the lowest was recorded in $\mathrm{C}_{1} \mathrm{~B}_{1} \mathrm{~S}_{2}$ (75\% cashew apple juice $+25 \%$ pineapple juice at inlet temperature of $170{ }^{\circ} \mathrm{C}$ with flow rate of $10 \mathrm{ml} / \mathrm{min}$ under ambient condition at $15^{\text {th }}$ day of storage) of $10.10^{\circ}$ Brix (Table-3).

The TSS increased with gradual passage of storage time, which might be due to hydrolysis of polysaccharides into monosaccharide and oligosaccharides. Similar results were also reported by Deka and Sethi (2001) in juice blends and Deka (2000) found an increasing trend in total soluble solids during storage at ambient and low temperature in lime - aonla and mangopineapple spiced RTS beverages. However, this rise in TSS is functional to storage temperature and a direct relation has been reported between increase in TSS and storage temperature. This might be correlated with lower rate of hydrolysis of sugars, polysaccharides and organic acids at lower 
temperature following the La Chatelier Principles of chemical reactions. Prasad and Mali (2000) observed that least increase in TSS under refrigerated storage of Kinnow juice due to reduced hydrolysis of polysaccharides and acids. Bhardwaj and Nandal (2014) had also proposed similar finding to show that TSS of blended Kinnow juice is directly correlated with storage duration and increase in TSS is higher at ambient condition due to high rate of solubilization or hydrolysis of acid into sugars. Similar, findings have been confirmed by Deka and Sethi (2001) in mixed fruit juice spiced beverage, Singh and Mathur (1953) in cashew apple juice and Bhardwaj and Mukherjee (2011) in Kinnow juice.

\section{Titrable acidity (\%)}

Among the blended juice treatment combinations, the highest titrable acidity of $0.65 \%$ was recorded in $\mathrm{B}_{4}(100 \%$ cashew apple juice at $150{ }^{\circ} \mathrm{C}$ inlet temperature with flow rate of $10 \mathrm{ml} / \mathrm{min}$ ) and the lowest was recorded in $\mathrm{B}_{2}(75 \%$ cashew apple juice + $25 \%$ pine apple juice powder at $160{ }^{\circ} \mathrm{C}$ inlet temperature with flow rate of $10 \mathrm{ml} / \mathrm{min}$ ) and $\mathrm{B}_{3}(75 \%$ cashew apple juice $+25 \%$ pine apple juice powder at $150{ }^{\circ} \mathrm{C}$ inlet temperature with flow rate of $10 \mathrm{ml} / \mathrm{min}$ ) of $0.42 \%$. Among the different storage conditions, the highest titrable acidity (\%) was recorded in $\mathrm{C}_{2}$ (refrigerated condition) of $0.50 \%$ and lowest was recorded in $\mathrm{C}_{1}$ (ambient condition) of $0.46 \%$.

Among the different days of storage the highest titrable acidity (\%) was recorded in $\mathrm{S}_{1}$ (0 day of storage) of $0.59 \%$ and lowest was recorded in $\mathrm{S}_{5}\left(60^{\text {th }}\right.$ day of storage $)$ of $0.38 \%$ (Table-1) The non significant differences were recorded for interaction effect of blended juice treatment combinations, storage conditions and days of storage.
This decreasing trend might be due to increased levels of sugars by hydrolysis and decreased levels of acidity. The release of acid by decomposition, hydrolysis, oxidation or fermentation which modifies the hydrogen ion concentration and consequently the change in acidity was occurred in RTS as reported by Jain et al., (1984) in oranges and Talasila et al., (2011). Teotia et al., (1992) noticed that titrable acidity of muskmelonmango beverage blends found decreased significantly with a consequent rise in Brix/acid ratio during the course of 6 months of storage.

\section{Reducing sugars (\%)}

Among the blended juice treatment combinations, the highest reducing sugars of $3.47 \%$ was recorded in $\mathrm{B}_{4}(100 \%$ Cashew apple juice at $150{ }^{\circ} \mathrm{C}$ inlet temperature with flow rate of $10 \mathrm{ml} / \mathrm{min})$ followed by $\mathrm{B}_{3}(75 \%$ cashew apple juice $+25 \%$ pine apple juice powder at $150{ }^{\circ} \mathrm{C}$ inlet temperature with flow rate of $10 \mathrm{ml} / \mathrm{min}$ ) of $3.26 \%$ and the lowest was recorded in $\mathrm{B}_{1}(75 \%$ cashew apple juice $+25 \%$ pine apple juice powder at $170{ }^{\circ} \mathrm{C}$ inlet temperature with flow rate of $10 \mathrm{ml} / \mathrm{min}$ ) of $3.20 \%$. The non significant differences were recorded for different storage conditions for reducing sugars (\%). Among the different days of storage the highest reducing sugars (\%) was recorded in $\mathrm{S}_{5}\left(60^{\text {th }}\right.$ day of storage) of $3.48 \%$ and lowest was recorded in $\mathrm{S}_{1}(0$ day of storage) of $3.08 \%$ (Table-1).

The reducing sugars of different blended juice treatment combinations varied from 3.06 to $3.10 \%$ at initial day of storage. Among the interaction effects of blended juice treatment combinations, storage conditions and days of storage recorded, the highest reducing sugars (\%) in treatment combination of $\mathrm{C}_{2} \mathrm{~B}_{4} \mathrm{~S}_{5}(100 \%$ cashew apple juice at inlet temperature of $150{ }^{\circ} \mathrm{C}$ with flow rate of 10 $\mathrm{ml} / \mathrm{min}$ under refrigerated condition at $60^{\text {th }}$ 
day of storage) of $3.81 \%$ followed by $\mathrm{C}_{1} \mathrm{~B}_{4} \mathrm{~S}_{5}$ (100\% cashew apple juice at inlet temperature of $150{ }^{\circ} \mathrm{C}$ with flow rate of $10 \mathrm{ml} / \mathrm{min}$ under ambient condition at $60^{\text {th }}$ day of storage) of $3.76 \%$ and the lowest was recorded in $\mathrm{C}_{1} \mathrm{~B}_{2} \mathrm{~S}_{2}$ (75\% cashew apple juice $+25 \%$ pineapple juice at inlet temperature of $160{ }^{\circ} \mathrm{C}$ with flow rate of $10 \mathrm{ml} / \mathrm{min}$ under ambient condition at $15^{\text {th }}$ day of storage) of $3.14 \%$ (Table-3).

This increasing trend of reducing sugars might be due to conversion of polysaccharides into reducing sugars in the presence of citric acid and also due to addition of sugars as reported by Sakhale et al., (2012) in mango RTS, Rustagi and Kumar (2013) in mango and amla blend and Mini et al.(2008) in cashew apple + mango jam.

\section{Total sugars (\%)}

Among the blended juice treatment combinations, the highest total sugars of $9.16 \%$ was recorded in $\mathrm{B}_{4}(100 \%$ cashew apple juice at $150{ }^{\circ} \mathrm{C}$ inlet temperature with flow rate of $10 \mathrm{ml} / \mathrm{min})$ followed by $\mathrm{B}_{3}(75 \%$ cashew apple juice $+25 \%$ pine apple juice powder at $150{ }^{\circ} \mathrm{C}$ inlet temperature with flow rate of $10 \mathrm{ml} / \mathrm{min}$ ) of $9.07 \%$ and the lowest was recorded in $\mathrm{B}_{1}(75 \%$ cashew apple juice $+25 \%$ pine apple juice powder at $170{ }^{\circ} \mathrm{C}$ inlet temperature with flow rate of $10 \mathrm{ml} / \mathrm{min}$ ) of $8.89 \%$.

The non significant differences were recorded at different storage conditions for total sugars (\%). Among the different days of storage the highest total sugars (\%) was recorded in $\mathrm{S}_{5}\left(60^{\text {th }}\right.$ day of storage $)$ of $9.08 \%$ and lowest was recorded in $\mathrm{S}_{2}\left(15^{\text {th }}\right.$ day of storage) of $8.95 \%$ (Table-1).

The total sugars of different blended juice treatment combinations varied from 8.52 to $9.10 \%$ at initial day of storage. Among the interaction effects of blended juice treatment combinations, storage conditions and days of storage recorded the highest total sugars (\%) in treatment combination of $\mathrm{C}_{2} \mathrm{~B}_{4} \mathrm{~S}_{5}(100 \%$ cashew apple juice at inlet temperature of 150 ${ }^{\circ} \mathrm{C}$ with flow rate of $10 \mathrm{ml} / \mathrm{min}$ under refrigerated condition at $60^{\text {th }}$ day of storage) of $9.28 \%$ followed by $\mathrm{C}_{2} \mathrm{~B}_{4} \mathrm{~S}_{4}(100 \%$ cashew apple juice at inlet temperature of $150{ }^{\circ} \mathrm{C}$ with flow rate of $10 \mathrm{ml} / \mathrm{min}$ under refrigerated condition at $45^{\text {th }}$ day of storage) of $9.25 \%$ and the lowest was recorded in $\mathrm{C}_{1} \mathrm{~B}_{1} \mathrm{~S}_{2}(75 \%$ cashew apple juice $+25 \%$ pineapple juice at inlet temperature of $170{ }^{\circ} \mathrm{C}$ with flow rate of $10 \mathrm{ml} / \mathrm{min}$ under ambient condition at $15^{\text {th }}$ day of storage) of $8.85 \%$ (Table-3).

The increase in the total sugars was observed as the advance of storage period. These results are in conformity with the Yadav (2010) in whey based banana herbal beverage during storage and Mini et al., (2008) in cashew apple + pineapple jam for six months period of storage.

\section{TSS/Acid ratio}

Among the blended juice treatment combinations, the highest TSS/Acid ratio of 25.85 was recorded in $\mathrm{B}_{3}(75 \%$ cashew apple juice $+25 \%$ pine apple juice powder at 150 ${ }^{\circ} \mathrm{C}$ inlet temperature with flow rate of 10 $\mathrm{ml} / \mathrm{min}$ ) followed by $\mathrm{B}_{2}(75 \%$ cashew apple juice $+25 \%$ pine apple juice powder at 160 ${ }^{\circ} \mathrm{C}$ inlet temperature with flow rate of 10 $\mathrm{ml} / \mathrm{min}$ ) of 25.39 and the lowest was recorded in $\mathrm{B}_{4}\left(100 \%\right.$ cashew apple juice at $150{ }^{\circ} \mathrm{C}$ inlet temperature with flow rate of $10 \mathrm{ml} / \mathrm{min}$ ) of 17.27. Among the different storage conditions, the highest TSS/Acid ratio was recorded in $\mathrm{C}_{1}$ (ambient condition) of 25.60 and lowest was recorded in $\mathrm{C}_{2}$ (refrigerated condition) of 21.18 .

Among the different days of storage the highest TSS/Acid ratio was recorded in $\mathrm{S}_{5}$ $\left(60^{\text {th }}\right.$ day of storage) of 30.66 and lowest was 
recorded in $S_{1}$ (0 day of storage) of 16.86 (Table-1).

The TSS/Acid ratio of different blended juice treatment combinations varied from 12.16 to 19.57 at initial day of storage. Among the interaction of blended juice treatment combinations, storage conditions and days of storage recorded the highest TSS/Acid ratio in treatment combination of $\mathrm{C}_{1} \mathrm{~B}_{3} \mathrm{~S}_{5} \quad(75 \%$ cashew apple juice $+25 \%$ pineapple juice at inlet temperature of $150^{\circ} \mathrm{C}$ with flow rate of $10 \mathrm{ml} / \mathrm{min}$ under ambient condition at $60^{\text {th }}$ day of storage) of 41.73 followed by $\mathrm{C}_{1} \mathrm{~B}_{2} \mathrm{~S}_{5}$ (75\% cashew apple juice $+25 \%$ pineapple juice at inlet temperature of $160{ }^{\circ} \mathrm{C}$ with flow rate of $10 \mathrm{ml} / \mathrm{min}$ under ambient condition at $60^{\text {th }}$ day of storage) of 38.89 and the lowest was recorded in $\mathrm{C}_{2} \mathrm{~B}_{4} \mathrm{~S}_{2}$ (100\% cashew apple juice at inlet temperature of $150{ }^{\circ} \mathrm{C}$ with flow rate of $10 \mathrm{ml} / \mathrm{min}$ under refrigerated condition at $15^{\text {th }}$ day of storage) of 13.09 (Table-3).

Increase in the TSS/Acid ratio was observed during the storage period. It is due to decrease of acidity and increase in total soluble solids. Similar results were also reported by Akinwale (2000) in cashew apple juice and Teotia et al., (1992) in muskmelon-mango blended beverage during the course of six months of storage.

\section{Ascorbic acid (mg/100 ml)}

Among the blended juice treatment combinations, the highest ascorbic acid of $197.91 \mathrm{mg} / 100 \mathrm{ml}$ was recorded in $\mathrm{B}_{4}(100 \%$ cashew apple juice at $150{ }^{\circ} \mathrm{C}$ inlet temperature with flow rate of $10 \mathrm{ml} / \mathrm{min}$ ) followed by $\mathrm{B}_{3}$ (75\% cashew apple juice $+25 \%$ pine apple juice powder at $150{ }^{\circ} \mathrm{C}$ inlet temperature with flow rate of $10 \mathrm{ml} / \mathrm{min}$ ) of $154.57 \mathrm{mg} / 100 \mathrm{ml}$ and the lowest was recorded in $\mathrm{B}_{1}(75 \%$ cashew apple juice $+25 \%$ pine apple juice powder at $170{ }^{\circ} \mathrm{C}$ inlet temperature with flow rate of $10 \mathrm{ml} / \mathrm{min}$ ) of $147.08 \mathrm{mg} / 100 \mathrm{ml}$.
Among the different storage conditions, the highest ascorbic acid was recorded in $\mathrm{C}_{2}$ (refrigerated condition) of $164.69 \mathrm{mg} / 100 \mathrm{ml}$ and lowest in $\mathrm{C}_{1}$ (ambient condition) of $161.38 \mathrm{mg} / 100 \mathrm{ml}$. Among the different days of storage the highest ascorbic acid was recorded in $S_{1}$ (0 day of storage) of 169.94 $\mathrm{mg} / 100 \mathrm{ml}$ and lowest in $\mathrm{S}_{5}\left(60^{\text {th }}\right.$ day of storage) of $156.20 \mathrm{mg} / 100 \mathrm{ml}$ (Table-1).

The ascorbic acid content of different blended juice treatment combinations varied from 149.33 to $216.75 \mathrm{mg} / 100 \mathrm{ml}$ at initial day of storage. Among the interaction effects of blended juice treatment combinations, storage conditions and days of storage recorded the highest ascorbic acid in treatment combination of $\mathrm{C}_{1} \mathrm{~B}_{4} \mathrm{~S}_{2}$ (100\% cashew apple juice at inlet temperature of $150{ }^{\circ} \mathrm{C}$ with flow rate of $10 \mathrm{ml} / \mathrm{min}$ under ambient condition at $15^{\text {th }}$ day of storage) of $208.25 \mathrm{mg} / 100 \mathrm{ml}$ followed by $\mathrm{C}_{2} \mathrm{~B}_{4} \mathrm{~S}_{2}$ (100\% cashew apple juice at inlet temperature of $150{ }^{\circ} \mathrm{C}$ with flow rate of $10 \mathrm{ml} / \mathrm{min}$ under refrigerated condition at $15^{\text {th }}$ day of storage) of $207.55 \mathrm{mg} / 100 \mathrm{ml}$ and the lowest was recorded in $\mathrm{C}_{1} \mathrm{~B}_{1} \mathrm{~S}_{5}(75 \%$ cashew apple juice at $+25 \%$ pineapple juice at inlet temperature of $170{ }^{\circ} \mathrm{C}$ with flow rate of $10 \mathrm{ml} / \mathrm{min}$ under ambient condition at $60^{\text {th }}$ day of storage) of $142.75 \mathrm{mg} / 100 \mathrm{ml}$ (Table3).

The ascorbic acid content of RTS decreased during storage with the advancement of storage period which was probably due to fact that ascorbic acid is sensitive to oxygen, light and heat which was easily oxidized in presence of oxygen by enzymatic and non enzymatic catalysts as stated by Mapson (1970). Similar results were also reported by Bhardwaj and Mukherjee (2011) in kinnow, aonla and ginger blended RTS. Christiane et al., (2008) studied the cashew apple ready-toserve beverage on the storage for 48 hours at $40{ }^{\circ} \mathrm{C}$ where it resulted in loss of ascorbic acid up to $8.8 \%$ for concentrated beverage 
and $6.4 \%$ for ready to serve juices prepared from cashew apple. Kumar and Deen (2017) reported in wood apple that the ascorbic acid content of RTS was decreased continuously during storage period.

\section{Tannins ( $\mathrm{mg} / \mathrm{ml})$}

Among the blended juice treatment combinations, the lowest tannins of 0.976 $\mathrm{mg} / \mathrm{ml}$ was recorded in $\mathrm{B}_{3}(75 \%$ cashew apple juice $+25 \%$ pineapple juice at $150{ }^{\circ} \mathrm{C}$ inlet temperature with flow rate of $10 \mathrm{ml} / \mathrm{min}$ ) followed by $\mathrm{B}_{2}(75 \%$ cashew apple juice + $25 \%$ pine apple juice powder at $160{ }^{\circ} \mathrm{C}$ inlet temperature with flow rate of $10 \mathrm{ml} / \mathrm{min}$ ) of $0.995 \mathrm{mg} / \mathrm{ml}$ and the highest was recorded in $\mathrm{B}_{1}(75 \%$ cashew apple juice $+25 \%$ pine apple juice powder at $170{ }^{\circ} \mathrm{C}$ inlet temperature with flow rate of $10 \mathrm{ml} / \mathrm{min}$ ) of $1.035 \mathrm{mg} / \mathrm{ml}$.

Among the different storage conditions, the lowest tannins was recorded in $\mathrm{C}_{1}$ (ambient condition) of $1.003 \mathrm{mg} / \mathrm{ml}$ and highest was recorded in $\mathrm{C}_{2}$ (refrigerated condition) of $1.010 \mathrm{mg} / \mathrm{ml}$. Among the different days of storage the lowest tannins was recorded in $\mathrm{S}_{5}$ $\left(60^{\text {th }}\right.$ day of storage) of $0.979 \mathrm{mg} / \mathrm{ml}$ and highest was recorded in $\mathrm{S}_{1}$ (0 day of storage) of $1.027 \mathrm{mg} / \mathrm{ml}$ (Table-1).

The tannins of different blended juice treatment combinations varied from 0.994 to 1.063 at initial day of storage. Among the interaction effects of blended juice treatment combinations, storage conditions and days of storage recorded the lowest tannins in treatment combination of $\mathrm{C}_{2} \mathrm{~B}_{2} \mathrm{~S}_{5} \quad(75 \%$ cashew apple juice $+25 \%$ pineapple juice at inlet temperature of $160{ }^{\circ} \mathrm{C}$ with flow rate of $10 \mathrm{ml} / \mathrm{min}$ under refrigerated condition at $60^{\text {th }}$ day of storage) of $0.961 \mathrm{mg} / \mathrm{ml}$ and the highest was recorded in $\mathrm{C}_{2} \mathrm{~B}_{4} \mathrm{~S}_{2} \quad(100 \%$ cashew apple juice at inlet temperature of 150 ${ }^{\circ} \mathrm{C}$ with flow rate of $10 \mathrm{ml} / \mathrm{min}$ under refrigerated condition at $15^{\text {th }}$ day of storage) of $1.044 \mathrm{mg} / \mathrm{ml}$. A gradual decrease in tannin content of RTS beverage was observed during storage (Table-3).

\section{Organoleptic evaluation}

\section{Colour}

Among the blended juice treatment combinations, the highest organoleptic score for colour of 7.82 was recorded in $\mathrm{B}_{2}(75 \%$ cashew apple juice $+25 \%$ pineapple juice at $160{ }^{\circ} \mathrm{C}$ inlet temperature with flow rate of 10 $\mathrm{ml} / \mathrm{min})$ followed by $\mathrm{B}_{3}(75 \%$ cashew apple juice $+25 \%$ pine apple juice powder at 150 ${ }^{\circ} \mathrm{C}$ inlet temperature with flow rate of 10 $\mathrm{ml} / \mathrm{min}$ ) of 7.60 and the lowest was recorded in $\mathrm{B}_{4}(100 \%$ cashew apple juice powder at $150{ }^{\circ} \mathrm{C}$ inlet temperature with flow rate of 10 $\mathrm{ml} / \mathrm{min}$ ) of 7.31.Among the different storage conditions, the highest organoleptic score of colour was recorded in $\mathrm{C}_{2}$ (refrigerated condition) of 7.68 and lowest was recorded in $\mathrm{C}_{1}$ (ambient condition) of 7.48. Among the different days of storage the highest organoleptic score for colour was recorded in $\mathrm{S}_{1}$ (0 day of storage) of 8.43 and lowest was recorded in $S_{5}\left(60^{\text {th }}\right.$ day of storage) of 6.52 (Table-2).

The organoleptic score for colour of different blended juice treatment combinations varied from 8.35 to 8.53 at initial day of storage. Among the interaction effects of blended juice treatment combinations, storage conditions and days of storage recorded the highest organoleptic score for colour in treatment combination of $\mathrm{C}_{2} \mathrm{~B}_{3} \mathrm{~S}_{2} \quad(75 \%$ cashew apple juice $+25 \%$ pineapple juice at inlet temperature of $150{ }^{\circ} \mathrm{C}$ with flow rate of $10 \mathrm{ml} / \mathrm{min}$ under refrigerated condition at $15^{\text {th }}$ day of storage) of 8.43 and the lowest was recorded in $\mathrm{C}_{1} \mathrm{~B}_{4} \mathrm{~S}_{5}$ (100\% cashew apple juice at inlet temperature of $150{ }^{\circ} \mathrm{C}$ with flow rate of $10 \mathrm{ml} / \mathrm{min}$ under ambient condition at $60^{\text {th }}$ day of storage) of 5.90 (Table-4). 
Table.1 Effect of blended juice treatment combinations, storage conditions and days of storage on different parameters of RTS beverage prepared by spray drying method

\begin{tabular}{|c|c|c|c|c|c|c|c|c|}
\hline Treatments & pH & $\begin{array}{c}\text { TSS } \\
(\text { (0 Brix) }\end{array}$ & $\begin{array}{c}\text { titrable } \\
\text { acidity }(\%)\end{array}$ & $\begin{array}{c}\text { Reducing } \\
\text { sugars }(\%)\end{array}$ & $\begin{array}{c}\text { Total } \\
\text { sugars } \\
(\%)\end{array}$ & $\begin{array}{l}\text { TSS/Acid } \\
\text { ratio }\end{array}$ & $\begin{array}{l}\text { Ascorbic acid } \\
(\mathrm{mg} / 100 \mathrm{ml})\end{array}$ & $\begin{array}{c}\text { Tannins } \\
\text { (mg/ } \\
\text { ml) }\end{array}$ \\
\hline B1 & 3.44 & 10.41 & 0.43 & 3.20 & 8.89 & 24.85 & 147.08 & 1.035 \\
\hline B2 & 3.42 & 10.45 & 0.42 & 3.23 & 8.97 & 25.39 & 152.57 & 0.995 \\
\hline B3 & 3.44 & 10.56 & 0.42 & 3.26 & 9.07 & 25.85 & 154.57 & 0.976 \\
\hline B4 & 3.38 & 10.61 & 0.65 & 3.47 & 9.16 & 17.27 & 197.91 & 1.018 \\
\hline SEm \pm & 0.01 & 0.01 & 0.01 & 0.004 & 0.01 & 0.05 & 0.30 & 0.003 \\
\hline CD (0.05) & 0.02 & 0.03 & 0.02 & 0.013 & 0.02 & 0.15 & 0.86 & 0.008 \\
\hline C1 & 3.38 & 10.55 & 0.46 & 3.29 & 9.03 & 25.60 & 161.38 & 1.003 \\
\hline $\mathrm{C} 2$ & 3.46 & 10.46 & 0.50 & 3.29 & 9.02 & 21.18 & 164.69 & 1.010 \\
\hline SEm \pm & 0.01 & 0.01 & 0.01 & 0.003 & 0.01 & 0.04 & 0.21 & 0.002 \\
\hline CD (0.05) & 0.03 & 0.02 & 0.03 & NS & NS & 0.11 & 0.61 & 0.006 \\
\hline S1 & 3.57 & 10.09 & 0.60 & 3.08 & 8.96 & 16.86 & 169.94 & 1.027 \\
\hline S2 & 3.52 & 10.20 & 0.55 & 3.20 & 8.99 & 18.60 & 167.27 & 1.026 \\
\hline S3 & 3.46 & 10.44 & 0.47 & 3.29 & 9.03 & 22.29 & 163.08 & 1.003 \\
\hline S4 & 3.35 & 10.79 & 0.40 & 3.40 & 9.05 & 28.29 & 158.67 & 0.994 \\
\hline S5 & 3.20 & 10.99 & 0.38 & 3.48 & 9.08 & 30.66 & 156.20 & 0.979 \\
\hline SEm \pm & 0.01 & 0.01 & 0.01 & 0.005 & 0.01 & 0.06 & 0.34 & 0.003 \\
\hline CD (0.05) & 0.02 & 0.04 & 0.02 & 0.014 & 0.02 & 0.17 & 0.96 & 0.009 \\
\hline
\end{tabular}

Table.2 Effect of blended juice treatment combinations, storage conditions and days of storage on organoleptic score of RTS beverage prepared by spray drying method

\begin{tabular}{|c|c|c|c|c|}
\hline Treatments & Colour & Flavour & Taste & Overall acceptability \\
\hline B1 & 7.58 & 7.32 & 7.62 & 7.30 \\
\hline B2 & 7.82 & 7.32 & 7.49 & 7.65 \\
\hline B3 & 7.60 & 7.19 & 7.28 & 6.89 \\
\hline B4 & 7.31 & 7.17 & 7.21 & 7.28 \\
\hline SEm \pm & 0.03 & 0.06 & 0.08 & 0.04 \\
\hline CD $(\mathbf{0 . 0 5})$ & 0.10 & 0.19 & 0.22 & 0.12 \\
\hline & & & & 7.05 \\
\hline C1 & 7.48 & 6.89 & 7.18 & 7.57 \\
\hline C2 & 7.68 & 7.60 & 7.62 & 0.03 \\
\hline SEm \pm & 0.02 & 0.05 & 0.05 & 0.08 \\
\hline CD $(\mathbf{0 . 0 5})$ & 0.07 & 0.13 & 0.15 & \\
\hline S1 & & & & 7.28 \\
\hline S2 & 8.43 & 8.35 & 8.41 & 7.27 \\
\hline S3 & 7.10 & 7.51 & 7.84 & 6.87 \\
\hline S4 & 7.66 & 7.21 & 7.44 & 6.18 \\
\hline S5 & 7.19 & 6.83 & 6.81 & 0.05 \\
\hline SEm \pm & 0.52 & 6.34 & 6.50 & 0.13 \\
\hline CD $(\mathbf{0 . 0 5})$ & 0.11 & 0.07 & 0.09 & \\
\hline & & 0.21 & 0.24 & \\
\hline
\end{tabular}


Table.3 Interaction Effect of blended juice treatment combinations, storage conditions and days of storage on different parameters of RTS beverage prepared by spray drying method

\begin{tabular}{|c|c|c|c|c|c|c|c|c|}
\hline Interactions & pH & $\begin{array}{c}\text { TSS } \\
\text { (0Brix) }\end{array}$ & $\begin{array}{c}\text { titrable } \\
\text { acidity } \\
(\%)\end{array}$ & $\begin{array}{c}\text { Reducing } \\
\text { sugars } \\
(\%)\end{array}$ & $\begin{array}{c}\text { Total } \\
\text { sugars } \\
(\%)\end{array}$ & $\begin{array}{l}\text { TSS/Acid } \\
\text { ratio }\end{array}$ & $\begin{array}{c}\text { Ascorbic acid } \\
(\mathrm{mg} / 100 \mathrm{ml})\end{array}$ & $\begin{array}{l}\text { Tannins } \\
(\mathrm{mg} / \mathrm{ml})\end{array}$ \\
\hline $\mathrm{B}_{1} \mathrm{C}_{1} \mathrm{~S}_{1}$ & 3.57 & 10.08 & 0.54 & 3.06 & 8.52 & 18.39 & 149.33 & 1.031 \\
\hline$B_{1} C_{1} S_{2}$ & 3.53 & 10.10 & 0.49 & 3.15 & 8.85 & 20.46 & 147.95 & 1.038 \\
\hline $\mathrm{B}_{1} \mathrm{C}_{1} \mathrm{~S}_{3}$ & 3.45 & 10.35 & 0.42 & 3.19 & 8.89 & 25.48 & 146.30 & 1.030 \\
\hline $\mathrm{B}_{1} \mathrm{C}_{1} \mathrm{~S}_{4}$ & 3.36 & 10.83 & 0.30 & 3.22 & 8.91 & 36.23 & 144.94 & 1.023 \\
\hline $\mathrm{B}_{1} \mathrm{C}_{1} \mathrm{~S}_{5}$ & 3.22 & 10.98 & 0.30 & 3.31 & 8.97 & 37.23 & 142.75 & 0.981 \\
\hline $\mathrm{B}_{2} \mathrm{C}_{1} \mathrm{~S}_{1}$ & 3.59 & 10.00 & 0.54 & 3.09 & 8.92 & 18.57 & 157.47 & 1.021 \\
\hline $\mathrm{B}_{2} \mathrm{C}_{1} \mathrm{~S}_{2}$ & 3.53 & 10.13 & 0.49 & 3.14 & 9.02 & 20.79 & 154.25 & 1.011 \\
\hline $\mathrm{B}_{2} \mathrm{C}_{1} \mathrm{~S}_{3}$ & 3.46 & 10.43 & 0.41 & 3.29 & 9.03 & 25.04 & 147.30 & 0.990 \\
\hline $\mathrm{B}_{2} \mathrm{C}_{1} \mathrm{~S}_{4}$ & 3.28 & 10.85 & 0.29 & 3.30 & 9.05 & 37.89 & 146.22 & 0,985 \\
\hline $\mathrm{B}_{2} \mathrm{C}_{1} \mathrm{~S}_{5}$ & 3.05 & 11.00 & 0.29 & 3.36 & 9.07 & 38.89 & 144.45 & 0.980 \\
\hline $\mathrm{B}_{3} \mathrm{C}_{1} \mathrm{~S}_{1}$ & 3.55 & 10.03 & 0.55 & 3.08 & 9.02 & 18.33 & 156.23 & 0.994 \\
\hline $\mathrm{B}_{3} \mathrm{C}_{1} \mathrm{~S}_{2}$ & 3.52 & 10.23 & 0.51 & 3.18 & 9.05 & 20.15 & 155.23 & 0.984 \\
\hline $\mathrm{B}_{3} \mathrm{C}_{1} \mathrm{~S}_{3}$ & 3.49 & 10.43 & 0.41 & 3.26 & 9.07 & 24.60 & 154.23 & 0.973 \\
\hline $\mathrm{B}_{3} \mathrm{C}_{1} \mathrm{~S}_{4}$ & 3.31 & 11.05 & 0.31 & 3.40 & 9.12 & 34,24 & 152.62 & 0.971 \\
\hline $\mathrm{B}_{3} \mathrm{C}_{1} \mathrm{~S}_{5}$ & 3.02 & 11.18 & 0.28 & 3.43 & 9.14 & 41.73 & 151.05 & 0.969 \\
\hline $\mathrm{B}_{4} \mathrm{C}_{1} \mathrm{~S}_{1}$ & 3.56 & 10.28 & 0.82 & 3.10 & 9.10 & 12.16 & 216.75 & 1.063 \\
\hline $\mathrm{B}_{4} \mathrm{C}_{1} \mathrm{~S}_{2}$ & 3.49 & 10.33 & 0.78 & 3.41 & 9.12 & 13.34 & 208.75 & 1.039 \\
\hline $\mathrm{B}_{4} \mathrm{C}_{1} \mathrm{~S}_{3}$ & 3.39 & 10.55 & 0.58 & 3.47 & 9.14 & 18.46 & 196.70 & 1.014 \\
\hline $\mathrm{B}_{4} \mathrm{C}_{1} \mathrm{~S}_{4}$ & 3.29 & 11.00 & 0.46 & 3.70 & 9.15 & 23.91 & 180.60 & 0.995 \\
\hline $\mathrm{B}_{4} \mathrm{C}_{1} \mathrm{~S}_{5}$ & 2.99 & 11.28 & 0.44 & 3.76 & 9.17 & 26.24 & 174.90 & 0.962 \\
\hline $\mathrm{B}_{1} \mathrm{C}_{2} \mathrm{~S}_{1}$ & 3.57 & 10.08 & 0.54 & 3.06 & 8.52 & 18.39 & 149.33 & 1.031 \\
\hline $\mathrm{B}_{1} \mathbf{C}_{2} \mathrm{~S}_{2}$ & 3.52 & 10.28 & 0.50 & 3.14 & 8.86 & 20.05 & 149.65 & 1.093 \\
\hline $\mathrm{B}_{1} \mathrm{C}_{2} \mathrm{~S}_{3}$ & 3.47 & 10.33 & 0.46 & 3.24 & 8.89 & 21.26 & 148.22 & 1.048 \\
\hline $\mathbf{B}_{1} \mathbf{C}_{2} \mathbf{S}_{4}$ & 3.39 & 10.43 & 0.44 & 3.31 & 8.90 & 23.66 & 147.70 & 1.045 \\
\hline $\mathrm{B}_{1} \mathrm{C}_{2} \mathrm{~S}_{5}$ & 3.35 & 10.63 & 0.40 & 3.34 & 8.91 & 27.32 & 144.70 & 1.034 \\
\hline $\mathbf{B}_{2} \mathbf{C}_{2} \mathrm{~S}_{1}$ & 3.59 & 10.00 & 0.54 & 3.09 & 8.92 & 19.57 & 157.47 & 1.021 \\
\hline $\mathbf{B}_{2} \mathbf{C}_{2} \mathrm{~S}_{2}$ & 3.53 & 10.23 & 0.47 & 3.16 & 8.87 & 20.38 & 156.30 & 1.011 \\
\hline $\mathrm{B}_{2} \mathrm{C}_{2} \mathrm{~S}_{3}$ & 3.47 & 10.38 & 0.43 & 3.25 & 8.93 & 23.78 & 155.75 & 0.993 \\
\hline $\mathbf{B}_{2} \mathbf{C}_{2} \mathbf{S}_{4}$ & 3.39 & 10.63 & 0.40 & 3.27 & 8.98 & 23.42 & 153.75 & 0.973 \\
\hline $\mathbf{B}_{2} \mathbf{C}_{2} \mathbf{S}_{5}$ & 3.37 & 10.83 & 0.38 & 3.40 & 9.02 & 26.64 & 152.70 & 0.961 \\
\hline $\mathrm{B}_{3} \mathrm{C}_{2} \mathrm{~S}_{1}$ & 3.55 & 10.03 & 0.55 & 3.08 & 9.02 & 18.33 & 156.23 & 0.994 \\
\hline $\mathrm{B}_{3} \mathrm{C}_{2} \mathrm{~S}_{2}$ & 3.54 & 10.23 & 0.47 & 3.14 & 9.03 & 20.59 & 156.10 & 0.993 \\
\hline $\mathrm{B}_{3} \mathrm{C}_{2} \mathrm{~S}_{3}$ & 3.53 & 10.63 & 0.40 & 3.24 & 9.06 & 24.31 & 155.90 & 0.964 \\
\hline $\mathrm{B}_{3} \mathrm{C}_{2} \mathrm{~S}_{4}$ & 3.48 & 10.83 & 0.39 & 3.36 & 9.07 & 28.07 & 154.29 & 0.962 \\
\hline $\mathrm{B}_{3} \mathrm{C}_{2} \mathrm{~S}_{5}$ & 3.42 & 11.00 & 0.39 & 3.39 & 9.11 & 28.15 & 150.25 & 0.962 \\
\hline $\mathrm{B}_{4} \mathrm{C}_{2} \mathrm{~S}_{1}$ & 3.56 & 10.28 & 0.82 & 3.10 & 9.10 & 12.16 & 216.75 & 1.063 \\
\hline $\mathrm{B}_{4} \mathrm{C}_{2} \mathrm{~S}_{2}$ & 3.52 & 10.13 & 0.73 & 3.31 & 9.15 & 13.09 & 207.55 & 1.044 \\
\hline $\mathrm{B}_{4} \mathrm{C}_{2} \mathrm{~S}_{3}$ & 3.42 & 10.48 & 0.64 & 3.37 & 9.21 & 15.38 & 199.50 & 1.016 \\
\hline $\mathrm{B}_{4} \mathrm{C}_{2} \mathrm{~S}_{4}$ & 3.33 & 10.75 & 0.62 & 3.69 & 9.25 & 18.93 & 189.25 & 1.003 \\
\hline $\mathrm{B}_{4} \mathrm{C}_{2} \mathrm{~S}_{5}$ & 3.22 & 11.05 & 0.59 & 3.81 & 9.28 & 19.09 & 188.75 & 0.986 \\
\hline SEm \pm & 0.02 & 0.04 & 0.02 & 0.01 & 0.02 & 0.17 & 0.95 & 0.009 \\
\hline CD (0.05) & 0.05 & 0.11 & NS & 0.04 & 0.06 & 0.48 & 2.72 & 0.027 \\
\hline CV\% & 0.60 & 0.51 & 4.58 & 0.61 & 0.36 & 1.02 & 0.82 & 1.265 \\
\hline
\end{tabular}


Table.4 Interaction Effect of blended juice treatment combinations, storage conditions and days of storage on organoleptic score of RTS beverage prepared by spray drying method

\begin{tabular}{|c|c|c|c|c|}
\hline Interactions & Colour & Flavour & Taste & Overall acceptability \\
\hline $\mathrm{B}_{1} \mathrm{C}_{1} \mathrm{~S}_{1}$ & 8.40 & 8.25 & 8.55 & 8.28 \\
\hline$B_{1} C_{1} S_{2}$ & 8.08 & 7.50 & 8.10 & 7.88 \\
\hline $\mathrm{B}_{1} \mathrm{C}_{1} \mathrm{~S}_{3}$ & 7.93 & 7.10 & 7.95 & 6.88 \\
\hline $\mathrm{B}_{1} \mathrm{C}_{1} \mathrm{~S}_{4}$ & 7.10 & 6.60 & 7.30 & 6.53 \\
\hline $\mathrm{B}_{1} \mathrm{C}_{1} \mathrm{~S}_{5}$ & 6.25 & 6.20 & 6.35 & 5.73 \\
\hline$B_{2} C_{1} S_{1}$ & 8.53 & 8.45 & 8.50 & 8.53 \\
\hline$B_{2} C_{1} S_{2}$ & 8.33 & 6.80 & 7.70 & 7.80 \\
\hline $\mathrm{B}_{2} \mathrm{C}_{1} \mathrm{~S}_{3}$ & 7.80 & 6.55 & 7.40 & 7.65 \\
\hline $\mathrm{B}_{2} \mathrm{C}_{1} \mathrm{~S}_{4}$ & 6.85 & 6.25 & 6.85 & 7.35 \\
\hline $\mathrm{B}_{2} \mathrm{C}_{1} \mathrm{~S}_{5}$ & 6.48 & 5.80 & 6.50 & 5.90 \\
\hline $\mathrm{B}_{3} \mathrm{C}_{1} \mathrm{~S}_{1}$ & 8.43 & 8.35 & 8.35 & 7.98 \\
\hline $\mathrm{B}_{3} \mathrm{C}_{1} \mathrm{~S}_{2}$ & 7.95 & 7.25 & 7.75 & 7.53 \\
\hline $\mathrm{B}_{3} \mathrm{C}_{1} \mathrm{~S}_{3}$ & 7.70 & 7.05 & 7.40 & 7.05 \\
\hline $\mathrm{B}_{3} \mathrm{C}_{1} \mathrm{~S}_{4}$ & 7.05 & 6.30 & 6.35 & 6.15 \\
\hline $\mathrm{B}_{3} \mathrm{C}_{1} \mathrm{~S}_{5}$ & 6.35 & 5.10 & 5.35 & 5.48 \\
\hline $\mathrm{B}_{4} \mathrm{C}_{1} \mathrm{~S}_{1}$ & 8.35 & 8.35 & 8.25 & 8.35 \\
\hline $\mathrm{B}_{4} \mathrm{C}_{1} \mathrm{~S}_{2}$ & 8.00 & 7.05 & 7.85 & 7.65 \\
\hline $\mathrm{B}_{4} \mathrm{C}_{1} \mathrm{~S}_{3}$ & 7.13 & 6.55 & 6.70 & 6.80 \\
\hline $\mathrm{B}_{4} \mathrm{C}_{1} \mathrm{~S}_{4}$ & 7.03 & 6.35 & 5.40 & 6.65 \\
\hline $\mathrm{B}_{4} \mathrm{C}_{1} \mathrm{~S}_{5}$ & 5.90 & 6.00 & 5.05 & 4.88 \\
\hline $\mathrm{B}_{1} \mathrm{C}_{2} \mathrm{~S}_{1}$ & 8.40 & 8.25 & 8.55 & 8.28 \\
\hline $\mathrm{B}_{1} \mathrm{C}_{2} \mathrm{~S}_{2}$ & 8.18 & 7.90 & 7.75 & 8.13 \\
\hline $\mathrm{B}_{1} \mathrm{C}_{2} \mathrm{~S}_{3}$ & 8.00 & 7.60 & 7.60 & 7.48 \\
\hline $\mathrm{B}_{1} \mathrm{C}_{2} \mathrm{~S}_{4}$ & 7.50 & 7.30 & 6.65 & 7.00 \\
\hline $\mathrm{B}_{1} \mathrm{C}_{2} \mathrm{~S}_{5}$ & 6.00 & 6.45 & 7.40 & 6.80 \\
\hline $\mathrm{B}_{2} \mathrm{C}_{2} \mathrm{~S}_{1}$ & 8.53 & 8.45 & 8.50 & 8.53 \\
\hline $\mathrm{B}_{2} \mathrm{C}_{2} \mathrm{~S}_{2}$ & 8.23 & 8.10 & 7.80 & 8.28 \\
\hline $\mathrm{B}_{2} \mathrm{C}_{2} \mathrm{~S}_{3}$ & 8.07 & 8.00 & 7.40 & 7.73 \\
\hline $\mathrm{B}_{2} \mathrm{C}_{2} \mathrm{~S}_{4}$ & 7.88 & 7.45 & 7.20 & 7.48 \\
\hline $\mathrm{B}_{2} \mathrm{C}_{2} \mathrm{~S}_{5}$ & 7.58 & 7.30 & 7.08 & 7.28 \\
\hline $\mathrm{B}_{3} \mathrm{C}_{2} \mathrm{~S}_{1}$ & 8.43 & 8.35 & 8.35 & 7.98 \\
\hline $\mathrm{B}_{3} \mathrm{C}_{2} \mathrm{~S}_{2}$ & 8.43 & 7.65 & 7.75 & 7.23 \\
\hline $\mathrm{B}_{3} \mathrm{C}_{2} \mathrm{~S}_{3}$ & 7.60 & 7.55 & 7.25 & 6.90 \\
\hline $\mathrm{B}_{3} \mathrm{C}_{2} \mathrm{~S}_{4}$ & 7.28 & 7.25 & 7.25 & 6.45 \\
\hline $\mathrm{B}_{3} \mathrm{C}_{2} \mathrm{~S}_{5}$ & 6.83 & 7.00 & 7.00 & 6.13 \\
\hline $\mathrm{B}_{4} \mathrm{C}_{2} \mathrm{~S}_{1}$ & 8.35 & 8.35 & 8.25 & 8.35 \\
\hline $\mathrm{B}_{4} \mathrm{C}_{2} \mathrm{~S}_{2}$ & 7.65 & 7.80 & 8.00 & 7.88 \\
\hline $\mathrm{B}_{4} \mathrm{C}_{2} \mathrm{~S}_{3}$ & 7.05 & 7.30 & 7.85 & 7.70 \\
\hline $\mathrm{B}_{4} \mathrm{C}_{2} \mathrm{~S}_{4}$ & 6.85 & 7.10 & 7.50 & 7.33 \\
\hline $\mathbf{B}_{4} \mathbf{C}_{2} \mathbf{S}_{5}$ & 6.75 & 6.85 & 7.25 & 7.25 \\
\hline SEm \pm & 0.11 & 0.21 & 0.25 & 0.13 \\
\hline CD (0.05) & 0.31 & 0.60 & 0.70 & 0.37 \\
\hline CV\% & 1.97 & 4.08 & 4.71 & 2.50 \\
\hline
\end{tabular}


Plate.1 View of blended RTS beverage prepared from blended juice powders at initial, $15^{\text {th }}$ and $30^{\text {th }}$ day of storage under refrigerated conditions

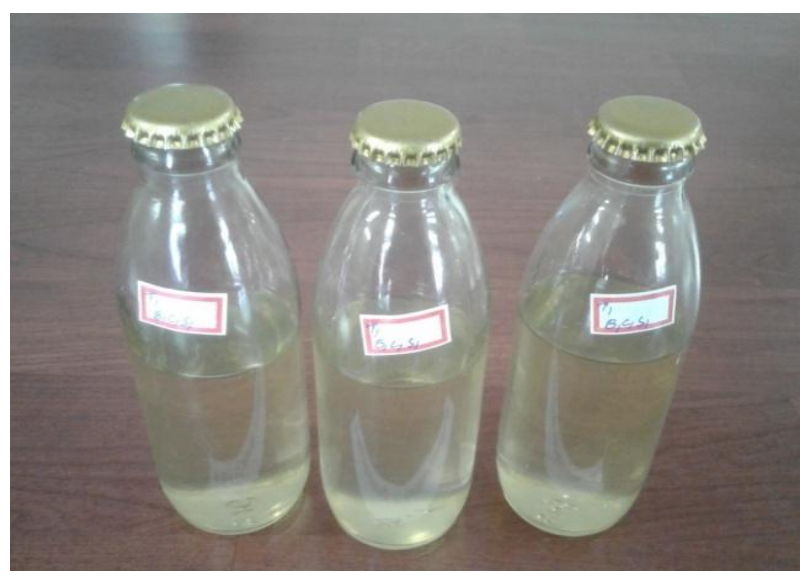

At initial day of storage

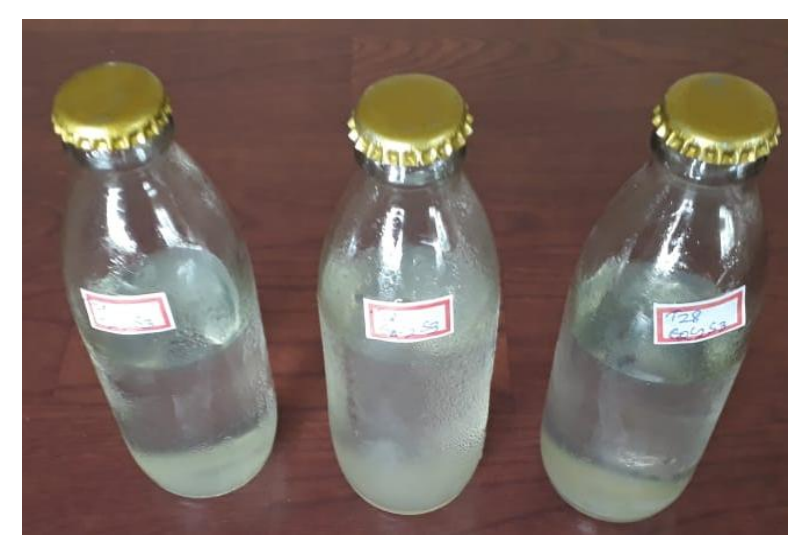

At $15^{\text {th }}$ day of storage

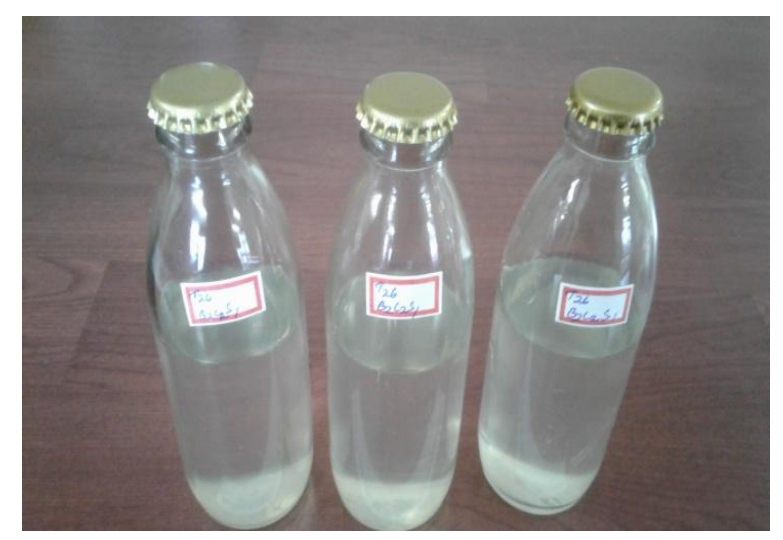

At $30^{\text {th }}$ day of storage 
Plate.2 View of RTS beverage prepared from blended juice powders in different treatment combinations at $45^{\text {th }}$ and $60^{\text {th }}$ day of storage under refrigerated condition
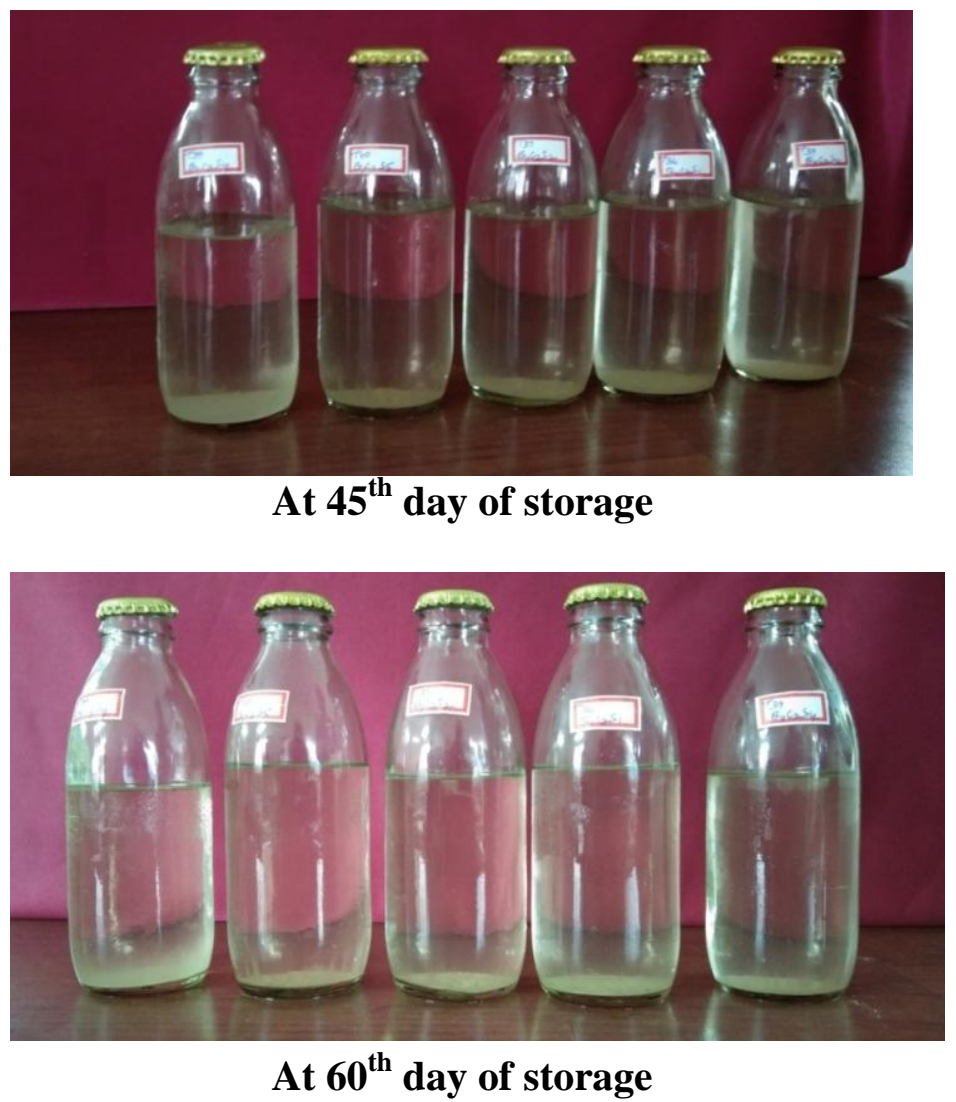

In the present study, results indicates that organoleptic score for colour, taste and over all acceptability in different treatments were decreased with advancement of storage period. Similar results were also reported by Bhardwaj and Mukherjee (2011) in kinnow, aonla and ginger blended RTS. The intension for organoleptic score was to incorporate the minimum possible quantity of pineapple juice in blend to get higher sensory score and adjustment of acidity to get good taste of RTS on blending with cashew apple juice. Roy et al., (2016) studied the organoleptic score for colour, taste and overall acceptability. It was decreased with advancement of storage period but RTS prepared from blend of $25 \%$ cashew apple juice $+75 \%$ mango juice blend followed by $25 \%$ cashew apple juice $+75 \%$ pineapple juice was stable up to 60 days.

\section{Flavour}

Among the blended cashew apple juice treatment combinations, the highest organoleptic score for flavour of 7.32 was recorded in $\mathrm{B}_{1}(75 \%$ cashew apple juice + $25 \%$ pineapple juice at $170{ }^{\circ} \mathrm{C}$ inlet temperature with flow rate of $10 \mathrm{ml} / \mathrm{min}$ ) and $\mathrm{B}_{2}(75 \%$ cashew apple juice $+25 \%$ pine apple juice powder at $160{ }^{\circ} \mathrm{C}$ inlet temperature with flow rate of $10 \mathrm{ml} / \mathrm{min}$ ) and the lowest was recorded in $\mathrm{B}_{4}(100 \%$ cashew apple juice powder at $150{ }^{\circ} \mathrm{C}$ inlet temperature with flow rate of $10 \mathrm{ml} / \mathrm{min}$ ) of 7.17 . Among the different storage conditions, the highest organoleptic score of flavour was recorded in $\mathrm{C}_{2}$ (refrigerated condition) of 7.60 and lowest was recorded in $\mathrm{C}_{1}$ (ambient condition) of 6.89(Table-2). 
Among the different days of storage the highest organoleptic score for flavour was recorded in $S_{1}$ (0 day of storage) of 8.35 and lowest was recorded in $\mathrm{S}_{5}\left(60^{\text {th }}\right.$ day of storage) of 6.34. The organoleptic score for flavour of different blended juice treatment combinations varied from 8.25 to 8.45 at initial day of storage.

Among the interaction effects of blended juice treatment combinations, storage conditions and days of storage recorded the highest organoleptic score for flavour in treatment combination of $\mathrm{C}_{1} \mathrm{~B}_{2} \mathrm{~S}_{2} \quad(75 \%$ cashew apple juice $+25 \%$ pineapple juice at inlet temperature of $160{ }^{\circ} \mathrm{C}$ with flow rate of $10 \mathrm{ml} / \mathrm{min}$ under ambient condition at $15^{\text {th }}$ day of storage) of 8.10 and the lowest was recorded in $\mathrm{C}_{1} \mathrm{~B}_{3} \mathrm{~S}_{5}$ (75\% cashew apple juice $+25 \%$ pineapple juice at inlet temperature of $150{ }^{\circ} \mathrm{C}$ with flow rate of $10 \mathrm{ml} / \mathrm{min}$ under ambient condition at $60^{\text {th }}$ day of storage) of 5.10 (Table-4).

The reduction in flavour was observed from 0 to $60^{\text {th }}$ day of storage. The reduction in flavour value was probably due to oxidation process the flavouring compounds viz., esters, aldehydes, acids, ketones, tannins and ethers got decreased and flavour value was also decreased. Rita and Virendra (2012) observed that the flavour of the custard apple RTS beverage was deteriorated with the advancement of storage period. Similar reduction in flavour was recorded by Saini et al., (2000) who observed some decline in flavour score of bottle kinnow juice stored under room temperature for a period of six months.

\section{Taste}

Among the blended juice treatment combinations, the highest organoleptic score for taste of 7.62 was recorded in $\mathrm{B}_{1}(75 \%$ cashew apple juice $+25 \%$ pineapple juice at
$170{ }^{\circ} \mathrm{C}$ inlet temperature with flow rate of 10 $\mathrm{ml} / \mathrm{min})$ followed by $\mathrm{B}_{2}(75 \%$ cashew apple juice $+25 \%$ pine apple juice powder at 160 ${ }^{\circ} \mathrm{C}$ inlet temperature with flow rate of 10 $\mathrm{ml} / \mathrm{min}$ ) of 7.49 and the lowest was recorded in $\mathrm{B}_{4}(100 \%$ cashew apple juice powder at $150{ }^{\circ} \mathrm{C}$ inlet temperature with flow rate of 10 $\mathrm{ml} / \mathrm{min}$ ) of 7.21 . Among the different storage conditions, the highest organoleptic score of taste was recorded in $\mathrm{C}_{2}$ (refrigerated condition) of 7.62 and lowest was recorded in $\mathrm{C}_{1}$ (ambient condition) of 7.18 (Table-2).

Among the different days of storage the highest organoleptic score for taste was recorded in $\mathrm{S}_{1}$ (0 day of storage) of 8.41 and lowest was recorded in $\mathrm{S}_{5}\left(60^{\text {th }}\right.$ day of storage) of 6.50. The organoleptic score for taste of different blended juice treatment combinations varied from 8.25 to 8.55 at initial day of storage.

Among the interaction effect of blended juice treatment combinations, storage conditions and days of storage recorded the highest organoleptic score for taste in treatment combination of $\mathrm{C}_{1} \mathrm{~B}_{1} \mathrm{~S}_{2}$ (75\% cashew apple juice $+25 \%$ pineapple juice at Inlet temperature of $170{ }^{\circ} \mathrm{C}$ with flow rate of 10 $\mathrm{ml} / \mathrm{min}$ under ambient condition at $15^{\text {th }}$ day of storage) of 8.10 and the lowest was recorded in $\mathrm{C}_{1} \mathrm{~B}_{4} \mathrm{~S}_{5}(100 \%$ cashew apple juice at inlet temperature of $150{ }^{\circ} \mathrm{C}$ with flow rate of 10 $\mathrm{ml} / \mathrm{min}$ under ambient condition at $60^{\text {th }}$ day of storage) of 5.05 (Table -4).

The reduction in the taste was observed from $0^{\text {th }}$ to $60^{\text {th }}$ day of storage. Sakhale et al., (2012) reported that the storage of whey based RTS beverage from mango cv. Kesar and the RTS beverage prepared with $70 \%$ whey and $30 \%$ mango juice recorded the maximum score for their sensorial quality attributes such as appearance, colour, flavour, taste, overall acceptability. 


\section{Overall acceptability}

Among the blended juice treatment combinations, the highest organoleptic score for overall acceptability of 7.65 was recorded in $\mathrm{B}_{2}(75 \%$ cashew apple juice $+25 \%$ pineapple juice at $160{ }^{\circ} \mathrm{C}$ inlet temperature with flow rate of $10 \mathrm{ml} / \mathrm{min}$ ) followed by $B_{1}$ (75\% cashew apple juice $+25 \%$ pineapple juice at $170{ }^{\circ} \mathrm{C}$ inlet temperature with flow rate of $10 \mathrm{ml} / \mathrm{min}$ ) of 7.30 and the lowest was recorded in $\mathrm{B}_{3}$ (75\% cashew apple juice + $25 \%$ pineapple juice at $150{ }^{\circ} \mathrm{C}$ inlet temperature with flow rate of $10 \mathrm{ml} / \mathrm{min}$ ) of 6.89.(Table-2).

Among the different storage conditions, the highest organoleptic score of overall acceptability was recorded in $\mathrm{C}_{2}$ (refrigerated condition) of 7.51 and lowest was recorded in $\mathrm{C}_{1}$ (ambient condition) of 7.05. Among the different days of storage the highest organoleptic score for overall acceptability was recorded in $S_{1}$ (0 day of storage) of 8.28 and lowest was recorded in $S_{5}\left(60^{\text {th }}\right.$ day of storage) of 6.18. The organoleptic score for taste of different blended juice treatment combinations varied from 7.98 to 8.53 at initial day of storage. Among the interaction effects of blended juice treatment combinations, storage conditions and days of storage recorded the highest organoleptic score for overall acceptability in treatment combination of $\mathrm{C}_{2} \mathrm{~B}_{2} \mathrm{~S}_{2}$ (75\% cashew apple juice $+25 \%$ pineapple juice at inlet temperature of $160{ }^{\circ} \mathrm{C}$ with flow rate of 10 $\mathrm{ml} / \mathrm{min}$ under refrigerated condition at $15^{\text {th }}$ day of storage) with score of 8.28 and the lowest score of 4.88 was recorded in $\mathrm{C}_{1} \mathrm{~B}_{4} \mathrm{~S}_{5}$ (100\% cashew apple juice at inlet temperature of $150{ }^{\circ} \mathrm{C}$ with flow rate of $10 \mathrm{ml} / \mathrm{min}$ under ambient condition at $60^{\text {th }}$ day of storage)(Table-4).

The reduction in the overall acceptability was observed from 0 to $60^{\text {th }}$ day of storage. Jain et al., (2011) reported decrease in overall acceptability of blended guava and papaya pulp at low temperature $\left(6 \pm 1^{\circ} \mathrm{C}\right)$ during storage. Afreen et al., (2016) observed the blend of carrot juice with sour-orange juices at the ratios of 50:50 received $6.66 \pm 0.087$ for overall acceptability.

\section{Microbial load units (CFU)}

The Microbial load (CFU) was revealed that, under ambient conditions up to 30 days of storage there was no incidence of bacteria, yeast and moulds. At 45 days after storage, observed the incidence of bacteria, yeasts and moulds in $75 \%$ cashew apple juice $+25 \%$ Pine apple juice at inlet temperature of $170{ }^{\circ} \mathrm{C}$ and at 60 days after storage, development of bacteria, yeasts and mould growth in reconstituted blended cashew juice of RTS at ambient conditions.

Under refrigerated condition, no incidence of bacteria, yeasts and mould growth was observed even upto 60 days after storage.

\section{References}

Afreen, S.M.M.S, Premakumar, K. and Inthujaa, Y. 2016. Development and storage stability of selected RTS beverage developed from carrot and sour orange blend. International Journal of Agriculture Innovations and Research. 4(6): 1010-1012.

Akinwale, T.O. 2000. Cashew apple juice its use in fortifying the nutritional quality of some tropical fruits. European Food Research Technology. 211: 205-207.

Awsi, J. and Masih, D.E.R. 2012. Development and quality evaluation of pineapple juice blend with carrot and orange juice. International Journal of Scientific and Research Publications. 2:1-8.

Azevedo, D.C.S. and Rodrigues, A.E. 2000. 
Obtainment of high -fructose solutions from cashew (Anacardium occidentale L.) apple by SMB chromatography. Separation Science and Technology. 35:2561-2581.

Bhardwaj, R.L. and Mukherjee, S. 2011. Effects of fruit juice blending ratios on kinnow juice preservation at ambient storage condition. African Journal of Food Science. 5(5):281- 286.

Bhardwaj, R.L. and Nandal, U. 2014 Effect of Storage Temperature on PhysicoChemical and Sensory Evaluation of Kinnow Mandarin Juice Blends. Journal of Food Processing and Technology. 5(8):1-4

Cano-Chauca, M, Stringheta, P.C, Ramos, A.M. and Cal-Vidal, I. 2005. Effect of the carriers on the microstructure of mango powder obtained by spray drying and its functional characterization. Innovative Food Science and Emerging Technologies 6(4): 420-428

Carvalho, J.M.D, Maia G.A. and Figueredo R.W.D 2007. Development of a blended non-alcoholic beverage composed of coconut water and cashew apple juice containing caffeine. Journal of Food Quality. 30: 664-681.

Chempakam, B. 1983. Distribution of ascorbic acid and ascorbic acid oxidase activity in the developing cashew apple (Anacardium occidentale L.). Journal of Horticulture Science. 58:447-448

Deka, B. C. 2000. preparation and storage of mixed fruit and storage of mixed fruit juice spliced beverage. Ph.D Thesis, IARI, New Delhi.

Deka, B. C. and V. Sethi (2001). Preparation of mixed fruit juice spiced RTS beverages. Indian Food Packer. 42(3) : 58-61.

Hubbali, V.N. 2019. Cashew productivity enhancement and value addition for doubling of farmers income. The Cashew and Cocoa Journal. 3(2): 13

Jain, P.K, Priyanka, J. and Prabhat, K. N. 2011. Quality of Guava and Papaya Fruit pulp as influenced by blending ration and storage period. American Journal of Food Technology. 6: 507512.

Jain, S.P, Tripathi, K.V, Ram, H.B. and Singh, S. 1984. Effect of storage conditions on the keeping quality of fruit squashes. Indian Food Packer. 38(5): 33-39.

Kumar, A. and Deen, B. 2017. Study on preparation and storage stability of wood apple RTS beverage. International Journal of Pure Applied Bioscience. 5(6): 879-886.

Maciel, M.I, Hansen, T.J., Aldinger, S.B and Laboes, J.N. 1986. Flavour chemistry of cashew apple juice. Journal of Agricultural and Food Chemistry. 34:923-927

Mapson, L. W. 1970. vitamins in fruits In Hulme, A. C. (Edn) The biochemistry of fruits and their products Academic Press, London, 1 : 369-384

Mini, C, Mathew and Indira, V. 2008. Changes in chemical and microbial quality of mixed cashew apple jams during storage. Journal of Plantation Crops. 36 (3): 496-499.

Nanjundaswamy, A.M. 1984. Economic utilization of cashew apple. Cashew causerie. 6 (2): 2-7.

Prasad, R.N. and Mali, P.C. (2000) Change in physico -chemical characteristics of pomegranate squash during storage. Indian Journal of Horticulture 57: 1820.

Rafeekher, M, Mini, C., Sudheer, K.P. and Geethalekshmy, P.R. 2015. Optimization of process parameters in spray drying of cashew apple juice. International Journal of Tropical Agriculture. 33(4):2563-2573 
Rita, M. and Virendra, S. 2012. Studies on microbial and sensory quality of custard apple RTS beverage. The Asian Journal of Horticulture. 7( 2):460-464.

Roy, A, Prasanna Kumar, B, Swami, D.V. and Subbramamma, P. 2016 Effect of blending of cashew apple (Anacardium occidentale L.) juice with mango, pineapple and sapota juice for the quality of rts beverage and its economic feasibility. Journal of Food Product Development and Packaging. 3:12-18.

Sakhale, B.K, Pawar, V.N. and Ranveer, R.C. 2012. Studies on the development and storage of whey based RTS beverage from Mango cv. Kesar. Journal of Food Processing Technology. 3:148.

Shreshta, A.K, Ua-Aruk, T, Adhikari, B.R, Howes, T. and Bhandari, B.R. 2007. Glass transition behavior of spray dried orange juice powder measured by differential scanning calorimetry (DSC) and thermal mechanical compression test (TMCT). International Journal of Food Processing. 10(3): 661-673.

Srivastava, R.P. and. Kumar, S. 2002 Fruits and vegetable Preservation: Principles and Practices. International Book Distributing company, Lucknow. Pp 184-185.

Saini, S, Sogi, D. S, and Bawa, A. S. 2000. Shelf-life studies on chemically preserved sand pear (Pyrus pyrifolia cv. patharnakh) pulp. Mysore- Journal of Food Science and Technology. 40: 230232.

Talasila, U, Rama Rao, V. and Khasim, B.S. 2011. Preservation and shelf life extension of cashew apple juice. International Journal of Food Safety. 13:275-280.

Teotia, M.S. Saxena, A.K. and Berry, S.K. 1992. Studies on the development of muskmelon mango beverage blends. Beverage and Food world. 19(2):29-30.

Yadav, R.B, Yadav, B.S. and Kalia, N. 2010. Development and storage studies on whey-based banana herbal (Mentha arvensis) beverage. American Journal of Food Technology. 5 (2): 121-129.

\section{How to cite this article:}

Umamaheswara Rao, K., B. Prasanna Kumar, D. V. Swami, B. Salomi Sunnetha, K. Uma Krishna and Smith, DD. 2020. Studies on Physico-chemical Characters and Storage Behavior of Blended Cashew Apple Juice Powder for RTS Beverage. Int.J.Curr.Microbiol.App.Sci. 9(12): 503-520. doi: https://doi.org/10.20546/ijcmas.2020.912.060 